\title{
The uses of Betula pendula Roth among Hungarian Csángós and Székelys in Transylvania, Romania
}

\author{
Nóra Papp ${ }^{1 *}$, Dóra Czégényi ${ }^{2}$, Anita Hegedűs ${ }^{3}$, Tamás Morschhauser ${ }^{4}$, Cassandra L. Quave ${ }^{5}$, \\ Kevin Cianfaglione ${ }^{6}$, Andrea Pieroni ${ }^{7}$ \\ 1 Department of Pharmacognosy, University of Pécs, Rókus 2, 7624 Pécs, Hungary \\ ${ }^{2}$ Department of Hungarian Ethnography and Anthropology, University of Babeş-Bolyai of Cluj-Napoca, Horea 31, 400202 Cluj-Napoca, Romania \\ ${ }^{3}$ Department of Languages for Specific Purposes, University of Pécs, Rókus 2, 7624 Pécs, Hungary \\ ${ }^{4}$ Department of Plant Taxonomy and Geobotany, University of Pécs, Ifúság 6, 7624 Pécs, Hungary \\ ${ }^{5}$ Center for the Study of Human Health, Emory University, 550 Asbury Circle, Candler Library 107, Atlanta, GA 30322, USA \\ ${ }^{6} S$ chool of Biosciences and Veterinary Medicine, University of Camerino, Via Pontoni 5, 62032 Camerino (MC), Italy \\ 7 University of Gastronomic Sciences, Piazza Vittorio Emanuele 9, I-12060 Fr. Pollenzo, Bra (CN), Italy
}

\section{Abstract}

The aim of this work is to evaluate the ethnobotanical and ethnopharmacological use of Betula pendula Roth in various regions of Transylvania, in East and Central Romania. Silver birch is an important pioneer species in the country, which has traditionally been used in ethnomedicine, households and various customs. Among the ethnic groups, 55 informants from the Csángós and 68 from the Székelys were interviewed in six villages during field studies occurring between 2007 and 2012. Informants were asked questions about the medical and non-medical applications of B. pendula, focusing on the use of the leaf and woody parts in tools and customs, and on the collection and use of birch sap with its temporal change in local ethnomedicinal knowledge. Differences related to the use of birch among the studied areas were observed. The folk remedies prepared from the sap ("virics") and leaves were documented in local customs, with similar symbolic roles assigned to birch used in other countries. Sap collection was performed during interviews and by manual means. Four special section types on the trunk were presented, and data concerning the nutritional and ethnomedicinal use of the sap was recorded. Both the significance and use of birch sap have drastically decreased in Transylvania due to the appearance of new phytotherapeutical sources and to social changes caused by migration of young people. We found that this phenomenon is gradually leading to the disappearance traditional harvesting techniques, frequency of use and ethnomedicinal knowledge concerning B. pendula in the studied regions.

Keywords: silver birch; ethnobotany; medicinal plant; traditional knowledge; birch sap; virics

\section{Introduction}

The silver or white birch (Betula pendula Roth), which belongs to the Betulaceae family, is well known as a pioneer species tolerant to cold, and which is prevalent mainly in the boreal zone in Europe [1], Asia and North Africa [2], with a wide ecological amplitude, preferring moist acidic and airy soil [3,4]. Since the Paleolithic Age, the species has been well known for its use as timber, in household tools and in traditional medicine $[5,6]$, and as a magic element in various cultures [7-9].

The word nyír (birch) is one of the oldest (5000-6000 years old) Hungarian words in historical linguistics, originating in

\footnotetext{
* Corresponding author. Email: nora.papp@aok.pte.hu
}

Handling Editor: Łukasz Łuczaj the Ural Mountains. From this region, the ancient elements of the use of B. pendula have been brought to the Carpathian basin by migration of Hungarians [10]. Silver birch is linked to special names for different regions in Hungary (such as "Nyírség") based on its presence in the local vegetation. Several settlements were also named after the surrounding birch forest in Transylvania, such as "Nyíres", "Nyírfás" [11], "Nyírszeg", "Nyírkert", "Gyakornyír" and "Marosnyír" [12]. In these regions, the traditional Hungarian use of silver birch has remained in the archaic (not current) knowledge of the people, even more so than in Hungary.

The "European Pharmacopoeia VII" [13] includes only the leaf (Betulae folium) as the official drug part of B. pendula (in Romanian: "mesteacăn"), but the leaf, the bark (B. cortex), the bud and its essential oil (B. gemma, B. gemmae aetheroleum) are also commonly used in the official phytotherapy nowadays [14]. However, the official "Romanian Pharmacopoeia 
X" [15] has no current data on the species, but the leaf and the bark are applied in the traditional ethnomedicinal system in the country [16]. According to the earlier reported data on the traditional use of birch, this species plays a significant role in the everyday life of local people in Transylvania. The trunk and woody parts have been used in handicraft tools, as firewood and construction elements $[11,12,17]$. The leaf and bark have been known as colorant substances in decoctions, for dying linen and wool to yellow, green, brown or grey $[11,18,19]$. Specifically, the bark has been applied for tanning leathers, for making saltboxes and baskets, and for use as postcard substitutes during World War I [12,20]. In addition, leafy branches have been collected as a protective symbol against lightning [21], and to ornament the portals of churches and houses during weddings, and in front of the houses of unwed young women in May [11].

The birch sap ("succus") circulating in the woody parts before the foliage state from March to May has been described in the European ethnomedicine [22], complete with analyses of some compounds [23-25], but without official data in the present phytotherapy. The sweet sap is called "nyírvíz" (literally birch water), "virics" or "mezge", and has been documented as an ethnomedicinal remedy for various human diseases $[6,10,26-30]$ and in ethnoveterinary medicine [31-33], as well as in hair cosmetics [31-34]. Birch water was fermented or boiled in houses for cooking virics [35], and consumed as wine, beer, syrup or vinegar, and as a soft drink in the region in springtime [14,36-38]. The traditional extraction of sap, namely "viricselés", has been described in only a few reports in Transylvania $[11,31,36,39,40]$. In the 18th-19th century, the birch sap was sold in barrels as an important product in the Transylvanian markets and served as a significant source of income for the local people [31].
In the present study, the main goal was to collect and document the contemporary and evanescent local practices concerning silver birch in some isolated Transylvanian villages, and to compare these data with the traditional uses of the species in the past. The fieldwork concentrated on the harvesting, use and role of the leaf, trunk and bark, and mostly on the traditional collection method and usage of birch sap.

\section{Material and methods}

\section{Research area and population}

Selection of the study areas in Transylvania were based on the prevalence of birch-woods, on the availability of pharmacy, medical and veterinary service, and on the living knowledge of the multiple uses of birch among local people. Silver birch is common in low-level humid areas in the mountains all over the country or in the vicinity of turf-moors, especially in secondary succession or near the woodland line. It can be observed mainly after the deforestation of Picea abies (L.) Karst. and Fagus sylvatica L. $[41,42]$.

Transylvania is a multicultural part of Romania. For centuries, it has been inhabited by various ethnic groups (mainly Hungarian, German and Romanian speaking). The selected Hungarian speaking Székely and Csángó areas represent ethnic, cultural and linguistic islands according to Hammer et al. [43], living in close relationship with the forests and natural surroundings. The selected six villages in the four major areas, namely Úz-valley, Gyimes-valley, Homoród-valley and Erdővidék (Fig. 1) are isolated from major settlements (Tab. 1).

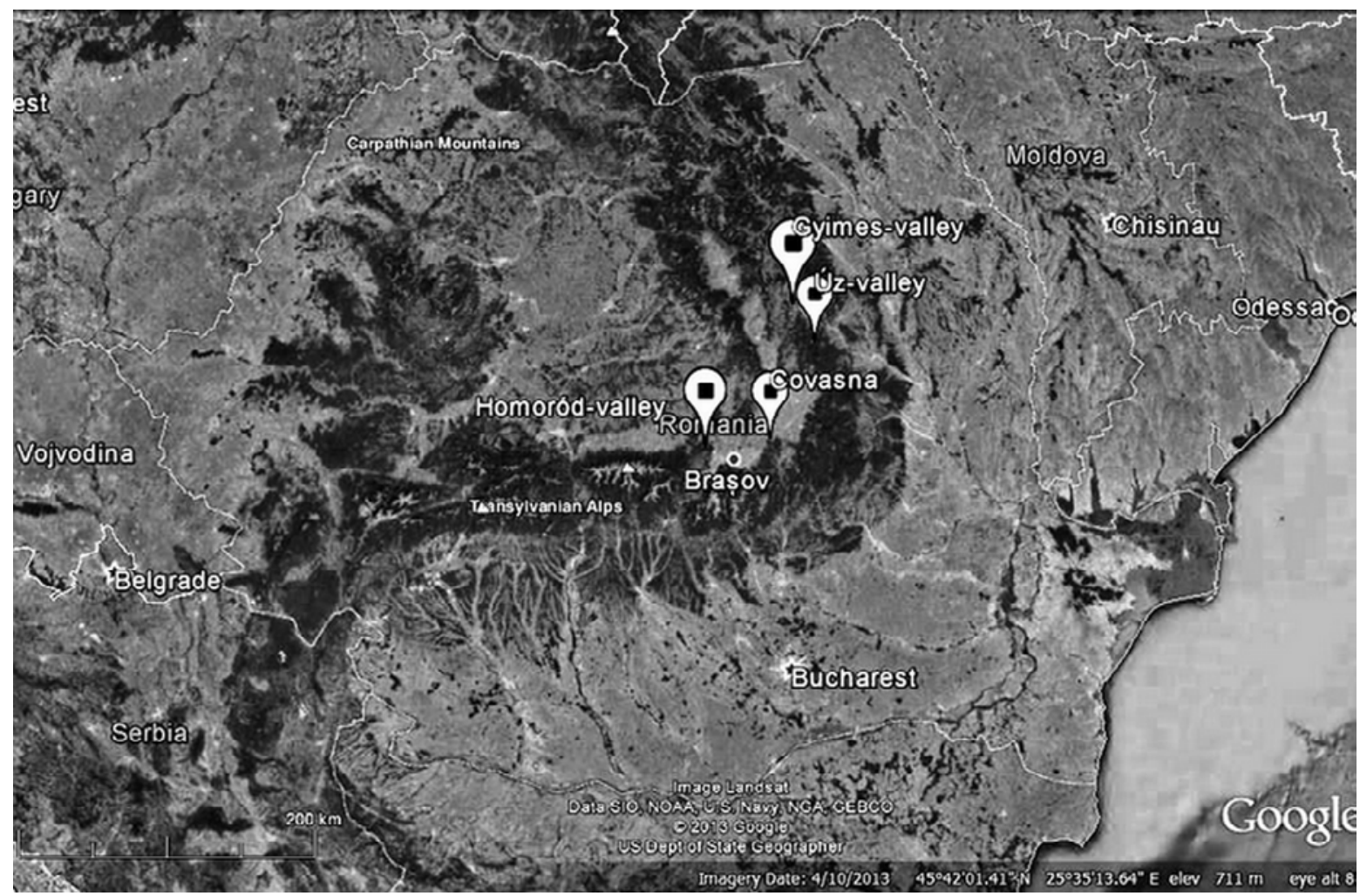

Fig. 1 Map of study areas (Google Earth 5.0, http://earth.google.com) 
Tab. 1 Study area in Transylvania.

\begin{tabular}{|c|c|c|c|c|c|c|c|}
\hline Study area & Latitude & Longitude & $\begin{array}{l}\text { Informants/ } \\
\text { Inhabitants }\end{array}$ & Confession & Medical service & $\begin{array}{l}\text { Veterinary } \\
\text { practice }\end{array}$ & Pharmacy \\
\hline 1. Gyimesfelsőlok & $46^{\circ} 31^{\prime} 44^{\prime \prime}$ & $25^{\circ} 57^{\prime} 33^{\prime \prime}$ & $17 / 650$ & Catholic & + & + & + \\
\hline 2. Csinód & $46^{\circ} 18^{\prime} 38^{\prime \prime}$ & $26^{\circ} 03^{\prime} 53^{\prime \prime}$ & $18 / 200$ & Catholic & - & - & - \\
\hline 3. Egerszék & $46^{\circ} 20^{\prime} 38^{\prime \prime}$ & $26^{\circ} 04^{\prime} 24^{\prime \prime}$ & $20 / 100$ & Catholic & - & - & - \\
\hline 4. Lövéte & $46^{\circ} 16^{\prime} 27^{\prime \prime}$ & $25^{\circ} 29^{\prime} 15^{\prime \prime}$ & $35 / 2900$ & Catholic & from a neighbouring settlement & + & + \\
\hline $\begin{array}{l}\text { 5. Homoród- } \\
\text { karácsonyfalva }\end{array}$ & $46^{\circ} 11^{\prime} 0^{\prime \prime}$ & $25^{\circ} 25^{\prime} 51^{\prime \prime}$ & $15 / 450$ & Unitarian & from a neighbouring settlement & - & - \\
\hline 6. Nagybacon & $46^{\circ} 522^{\prime \prime}$ & $25^{\circ} 41^{\prime} 29^{\prime \prime}$ & $18 / 1932$ & Catholic & + & + & + \\
\hline
\end{tabular}

Ethnic groups of the study areas. Csángós: Gyimes-valley (1), Úz-valley (2, 3); Székelys: Homoród-valley (4, 5), Erdővidék in Covasna county (6).

Local people use Hungarian as their native language in each village. In the Csángós' region in Úz-valley and Gyimes-valley, local people are subsistence farmers supplementing their income by making local dairy products and homespun clothes, and in special cases, folk costumes. In the case of acute health problems, people in Csinód (in Romanian: Cinod) and Egerszék (Egershec) of Úz-valley take a long trip to the major villages, which are provided with an own pharmacy and primary healthcare. In Gyimesfelsölok (Lunca de Sus) in Gyimes-valley in eastern Romania, the ancestral knowledge about the native flora is represented by unique magico-mythological methods and several local folk customs in the Csángós' ethnomedicine [38]. In Székely region in southern Transylvania, Homoród-valley consists of several villages along the river Kis-Homoród. Among them, in Lövéte (Lueta), people work in agriculture and in the industry of the neighboring settlements. The Viscum Pharmacy was established in the village in 2008 with many drugs and remedies providing a daily service for the people.

Also, along the river Kis-Homoród, inhabitants of Homoródkarácsonyfalva (Crăciunel) are employed as handworkers, and work in agriculture, livestock farming and apiculture. Specialists acquired wide experience about plants, based on their observations and on inherited data, too.

Inhabitants of Nagybacon (Bătani Mari) in Erdővidék work mainly in industry. The ethnomedicinal elements are completed by methods of official medicine in this village nowadays.

\section{Ethnobotanical collection}

Informants from randomly selected households in the study communities were interviewed in the summers of 2007-2011 and in the spring of 2012, using semi-structured and unstructured interviews [44], handwritten notes and photos throughout collecting fieldtrips in the mountains. The interviews were conducted with one person at a time. In questionnaires, the visited 123 informants (Tab. 1) aged between 14 and 99 years (the ratio of female/male informants was 2:1), were asked to list the harvesting methods and time, as well as the uses of the leaf, woody parts and bark of silver birch. The medicinal uses of the plant parts contained some records arising from official sources (e.g. books, journals), which were separated from the traditional data by questions aimed at the source of the knowledge. Only the medicinal data and the use in tools and customs mentioned by more than $75 \%$ of the informants were documented in this work.

With respect to the traditional collection of the sap, appropriate details were represented orally in summers in all studied regions, and manually on the trunk of the trees presented by 8 villagers ( 4 men from both Lövéte and Homoródkarácsonyfalva) throughout fieldtrips in April prior to the foliage period. The documentation of the process comprised the slit form, the height and form of the cut, and the collected quantity, storage and uses of the sap. In addition, people were interviewed about the role of the species in household tools and local ceremonies, and their uses as timber and firewood for non-medicinal purposes. The original quotations of the people were written in italics between inverted commas according to the folk terminology of Csángós and Székelys. Voucher specimens collected in each village were deposited at the Department of Pharmacognosy of the University of Pécs, Hungary.

\section{Results}

\section{Birch leaf and bark use in ethnomedicine}

In all regions, the ethnomedicinal use of silver birch was mentioned mostly by women, related to their activities focusing principally on the households. Among the parts of birch, in preparations of the leaf and the bark regional variations were observed (Tab. 2). The fresh or dry leaf was used by itself or blended with other species in various home remedies applied internally and externally, too. In the Csángós' region in Gyimes-valley and Úz-valley, the fresh collected leaves were applied as a diaphoretic foment spread on the bedding. People put their painful legs into a sac for the night or into trousers filled with birch leaves during the day, or they lie among them in bed to treat mostly rheumatisms, generally four or five times daily for some hours, or all 
Tab. 2 Traditional use of Betula pendula Roth in the studied villages and previous reports in Transylvania, and in other European countries.

Parts used and application forms in the studied Transylvanian villages
Previous reports in Transylvania

Data from other European countries

\section{Medicinal use Leaf: for cold as a foment; for} rheumatism and arthritis as a bath and foment (Gy) and in bed or in a sack as a foment; as a diuretic (Cs, L, H); for varicose veins in trousers and for waist pain as a foment; for kidney stones with Alnus glutinosa, Origanum vulgare and Equisetum arvense as a tea; for swollen legs with Achillea millefolium and Lysimachia nummularia for wounds (wound healing) chilblain, heart and liver disease; for flatulence as a tea $(\mathrm{L})$, for renal pain as tea or bath (Cs); for sweating of the legs $(\mathrm{L}, \mathrm{H}, \mathrm{N})$. Bark: for wounds $(\mathrm{N})$.

Sap: as a refreshing beverage earlier (Gy, H, N); for kidney disease (Cs, $\mathrm{H})$; for gall stones (E); as an appetite stimulant, for stomach and liver disease; for colds (E, L); for chilblain as a foment (L).
Leaf: decoctions containing only birch leaves $[18,49,50]$; for rheumatism as a foment in bed and sack [11,45-48]; for stroke with garlic and for cold as a tea [47]; as a diaphoretic [61].

Bark: in veterinary practice for diarrhoea and dysentery [61]. Sap: drained from the trunk in spring [26,31,36,81]; sold in the markets [31]; vermifuge; as a milk-rennet drug in cheese [26,27]; for colds [11,12]; for anaemia [82]; for constipation and pneumonia; for a fungal skin disease called semereg or ebsemereg $[12,28,29]$; $\quad$ [83]

for abscess and pimples [30]; for herpes Bark: for hemorrhoids (Pieroni, unpublished); called ebsömöreg [8]; as a vermifuge $[36,59,82]$.

Tar: for psoriasis and eczema as liniment, tincture and soap $[59,60]$.
Leaf: mostly in single remedies; among ancient data: for wounds [7]; for painful body parts [51,52]; as diuretic tea (Pieroni, unpublished) [55,56,62]; as a cholagogue, for gout, rheumatism, cold [55,56,62], fever and detoxication $[55,56]$; to treat urinary tract infections [54-56] and kidney stone [54]; in veterinary for diarrhoea in cows, for arthritis in suint [62].

Branches: internally: rain, which has gone through a birch tree, is collected and drunk to treat kidney stones and prostatitis; externally: beaten on the affected part to treat bruises for cold, fever, rheumatisms and purifying blood [55,56]; as a diuretic; for urinary tract infections [55-58]; externally: burned, the vapours are exposed to the skin to treat skin inflammations (Pieroni, unpublished). Sap: drained from the trunk in spring $[63,64]$; as a milk-rennet drug in cheese [77,78]; for children with milk in the teething period, for sores on the lower legs of humans [65].

Use in Branches (Gy, Cs, E, $\mathrm{L}, \mathrm{H}, \mathrm{N})$ and trunk Branches: for broom $[11,46]$.

household tools $(\mathrm{H})$ for broom; trunk in shaft, carriage and as firewood (L), and in tools (H).

Use in customs Leafy branches: from Csíksomlyó blessed at Whitsunday and burnt during a storm for protection $(\mathrm{Gy}$, Cs, E, H), blessed at Easter and Whitsunday, as an ornament at weddings and on May 1st for maidens $(\mathrm{L}, \mathrm{H})$, thrown in the fire during prayer (Cs).

Other uses Leaf: for hair loss (Gy, L), and for dyeing as a decoction $(\mathrm{Gy}, \mathrm{N})$.
Leafy branches: erected on May 1st for maidens [11].

Leaf: for dyeing as a decoction [11,53]. Sap: for sunspots [31], as a hair colorant with sugar [31-33], as a hair conditioner [34], as a beverage, wine, beer, syrup or vinegar [16,18,36-38].
Branches: for broom [7,79], in torches [7].
Leafy branches: used in wreath ornaments; apotropaic role against witches and bad spirits [7]; sacred and magic tree in rituals $[6,7]$; to make magistrates' beams "that everyone fears" [7]; erected on May 1st as a gift for unwed young women $[7,72]$ (Pieroni, unpublished data); used in herbal wreaths [84].
Leaf: as a surrogate of tobacco [6], for hair loss and dandruff [54].

Sap: as a hair conditioner [85], for hair growth as rubber recently [65]; eventually sugar and raisins are added to the fresh sap, and fermented in a cool and dark place for two months - the resulting liquid is drunk and considered very "healthy" (Pieroni, unpublished); as a beverage, wine, beer, syrup [65-74] and vinegar [65-76], earlier as a fresh or fermented drink with malt and wax, wine, syrup, vinegar and confectionery; in cosmetics in lotions and shampoos; the fresh or pasteurized beverage with lemon juice, sugar and raisins; sold in shops nowadays [65]. 
night. In addition, informants consider that this treatment is inadequate for sensitive patients, because "it can drain the strength from the muscles", causing asthenia and fatigue. In Homoród-valley in Lövéte and Homoródkarácsonyfalva, besides the independent application of the leaves, there were also reports of the use of birch leaves in combination with other taxa, such as with the herb of "egérfarkú fü" (Achillea millefolium L.), "piculavirág” (Lysimachia nummularia L.), "ezerjófü" (Origanum vulgare L.) and "surlófü" (Equisetum arvense L.), and with the leaf of "egörfa" [Alnus glutinosa (L.) Gaertn.] for different ailments. In Nagybacon, the fresh leaves were applied to promote heavy sweating of the legs, in the same way as in Homoród. Application of the bark was mentioned only in Nagybacon, applied to wounds as an anti-inflammatory drug, used mostly in captivity during World War II (Tab. 2).

\section{Collection and use of birch sap}

In contrast to the role of women as the main healers, men have knowledge about the growth habits, distribution and phenology of silver birch in the region. On a regional scale in Transylvania, special data were recorded on birch water (virics) and on the collecting method of the sap (viricselés). Besides the interviewed women who had no skills and knowledge about the collection, only 8 men could present the methods. The frequency of the extraction and the use of the sap is declining continuously in these days, because its consumption is replaced mostly by various refreshing beverages available in shops, and similar healing effects are achieved through the use of official remedies described in books.

In this process, young trees are bored or slit 3-4 times on average in the same spring, at about a height of one meter and mostly on the shady side of the mildly curved trunks, or on the lateral branches close to the trunk.

In Gyimes-valley, the trunk was bored in the lower part of the tree, and then an iron or copper tube was inserted in the hole, allowing the sap to flow into a jar or a pottery called "csipor". In Úz-valley, the virics was extracted by the section or boring of the trunk after breaking the thick branches.

In Székely regions, young trees were slit at the base or at the height of about one and a half meters by an axe or knife called a bicsok, resulting in the outflow of the sap from various sections. In Homoród-valley, altogether four section types were described during the collection, according to the recorded oral and manual presentations in forests (Fig. 2). Firstly, the bark can be slit in the form of " $T$ " or “ $\downarrow$ ", 1 centimeter deep, and 15 centimeters long vertically and horizontally (Fig. 2a-b). Then the extreme parts of the slit were bent up or down beside the central section, allowing the sap to leak into a jar with the help of a funnel. In the next type, the trunk was incised in a V-form "windowy" in two directions transversally (Fig. 1c), where the sap was let out through the bottom peak of the slit, in the same way as documented in Úz-valley (Fig. 3).

In the last section type, the sap can accumulate in a deep hole, namely "lik", "göbü" or "hajk" (their preparations are called göbüzés and hajkolás), similarly to the oral data in Gyimes-valley (Fig. 2d, Fig. 4). From these holes, the sap can be drained through a hollow plant stem as in the case of
Phragmites taxa, or collected in a jar (Fig. 5) with or without a funnel made from birch bark.

Based on the age of the tree and weather conditions, virics was observed in older trees visible as drops at the beginning of the spring, and as a continuous flow in the younger ones in the main period of the season, yielding 3-4 deciliters, sometimes 1-2 liters of fluid daily in three described section types (Fig. 2a-c), and about one deciliter in göbü (Fig. 2d). After collection, the scar of the holes and sections were smeared with mud or clay to "heal" the trunk of the tree.

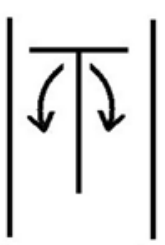

a

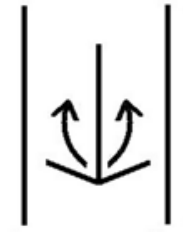

b

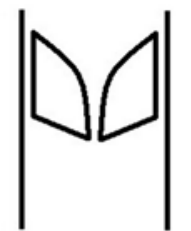

c

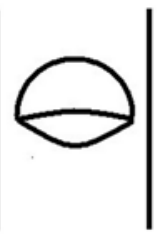

d
Fig. 2 Section types of the collection of birch sap on the trunk. a "T" type. b " $\downarrow$ " type. Arrows show the direction of the bending of the bark. c V-form type. d Göbü.

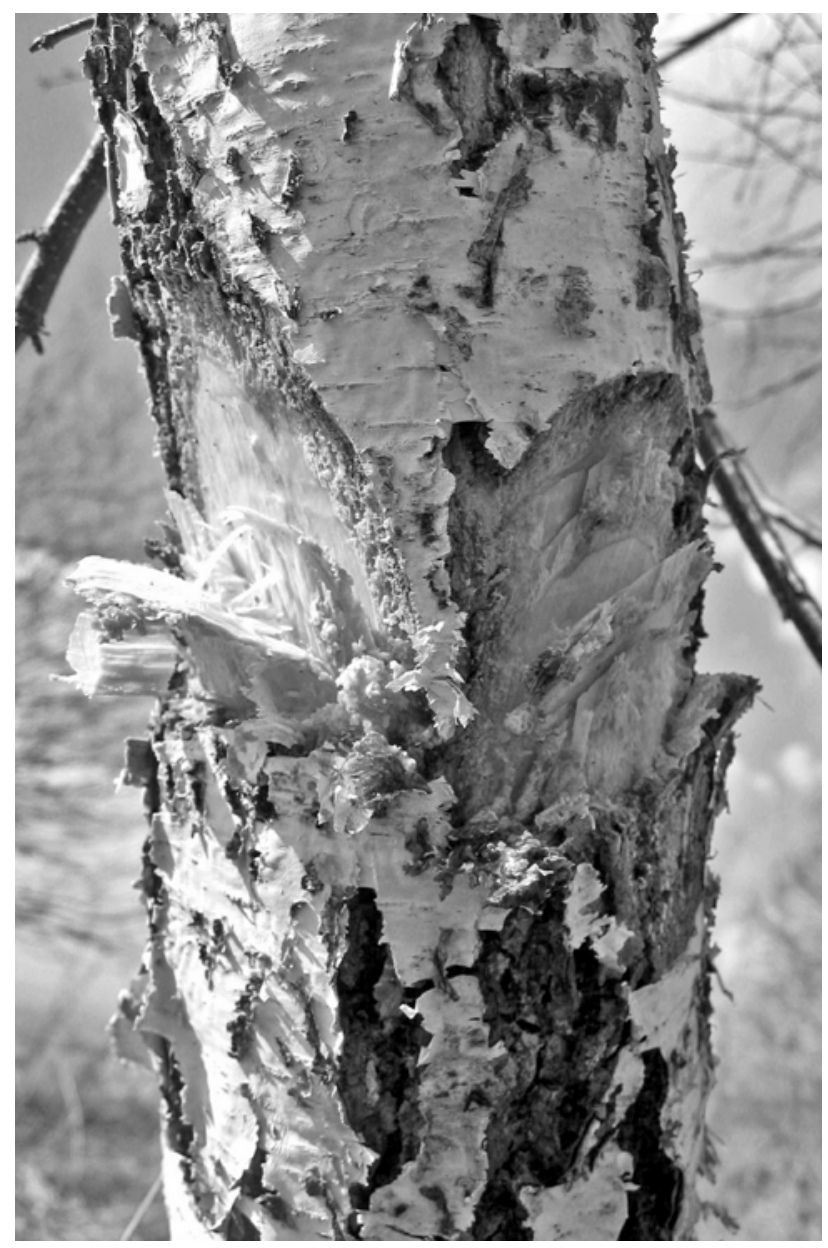

Fig. 3 V-form section in the collection of sap. 


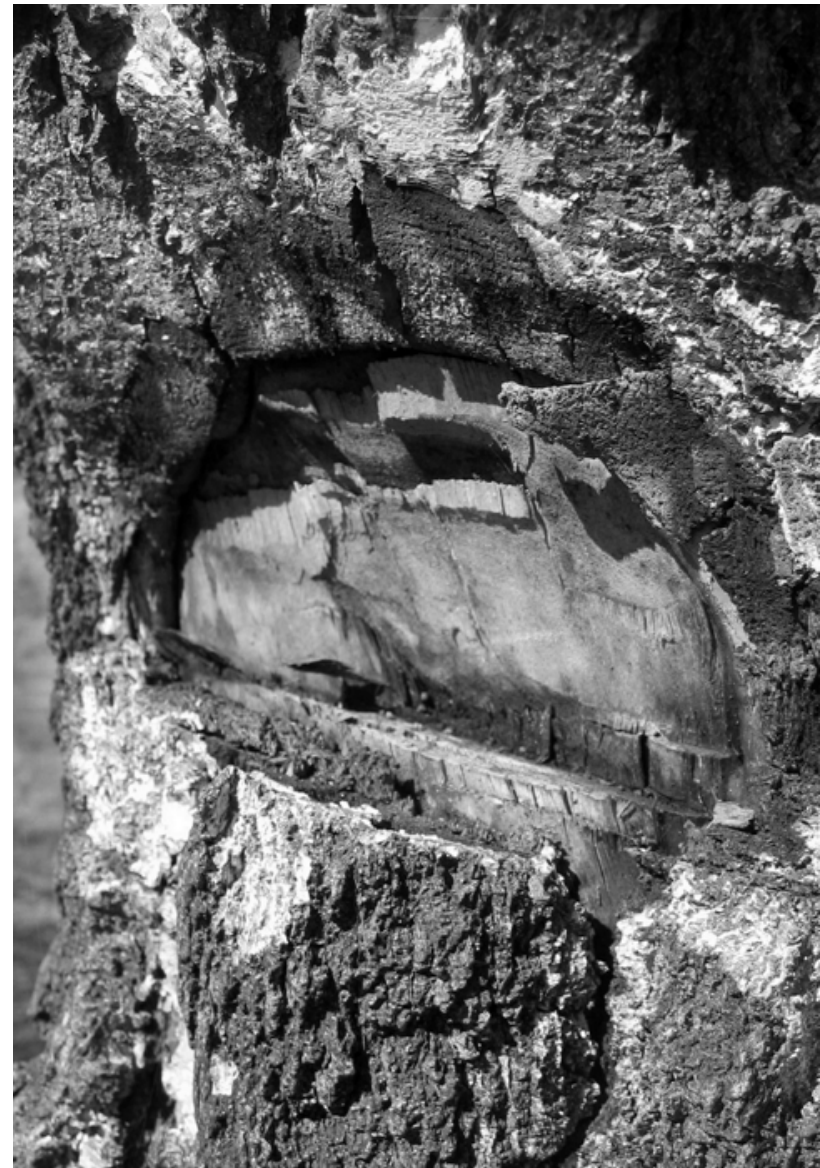

Fig. 4 Göbü in the collection of sap.

The collected sap can be stored in a cool cellar or in a fridge in covered jars for two weeks, and used before it becomes cloudy. According to the informants in Homoródvalley, its consumption is healthy during the whole summer, although the excessive use leads to headache. Most common uses of virics include a drink with curative power internally, and a foment externally in all studied villages (Tab. 2).

\section{Silver birch in household tools}

Similarly to the collection of birch sap, the use of other plant parts in tools (or tool construction) was presented mostly by men (Tab. 2). In Homoród-valley, the trunk and the thick branches were used as popular firewood because of the easily ignitable bark with high calorific value, and in household tools, such as in wooden forks, shafts, shovels or axes. It was especially common in two types of broom; about 15 thin and long wattles were bound by a ring called "káva" made from the bark pelt of "magyarófa" (Corylus avellana L.) in the first type (Fig. 6), and short twigs were tied on a thick lateral branch called "csutaksepru"” in the second one (Fig. 7). About 30-40 years ago, brooms were sold for various industries, presenting a significant livelihood activity for the local people.

\section{Silver birch in customs}

The use of $B$. pendula in local ceremonies and customs was listed both by women and men in each village. Csángós of Gyimes walk round the house with a birch broom three times

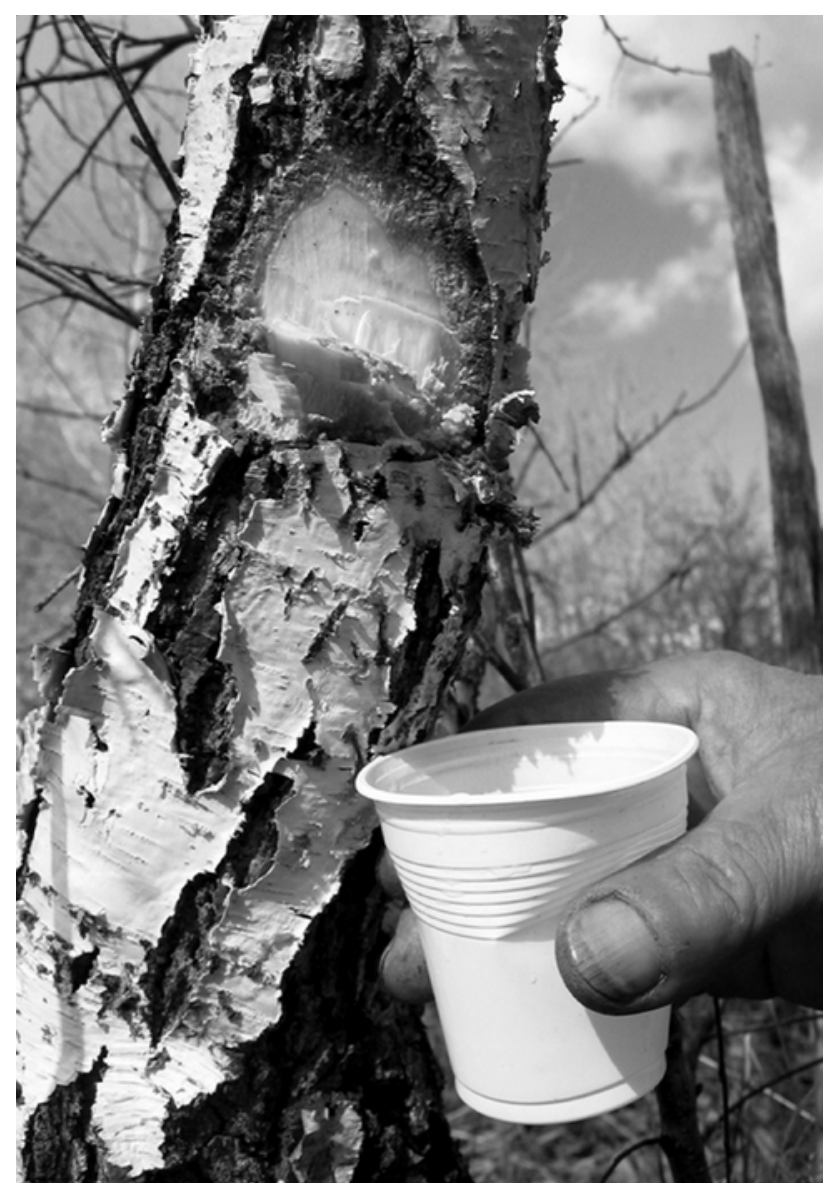

Fig. 5 Collection of sap.

at the night of St. George day (April 24th), to avoid reptiles getting into the house. During daytime, Csángó people of Úz-valley have stored the birch broom in the corner behind the door, but exclusively in the court at night as a rigorous custom in the region.

The blessing of the leafy branches is considered as a widespread traditional ceremony in Transylvania. People go on pilgrimage to Csíksomlyó at Whitsunday, praying to the Blessed Virgin at the famous catholic church of the settlement. During this trip, birch branches are blessed and taken home to say the Lord's Prayer and Ave Maria according to the number leaves on the branches. Moreover, in Csángós' regions, the blessed branches are thrown and burnt in the fire as protection from a storm, accompanied by a prayer repeated three times and by a special magic formula used as a protective symbol.

In the Transylvanian ceremonies, the leafy branches of silver birch, called "ződág” (green branch), play an important role in the ornamentation of crucifixes at roadsides, bridges and houses in weddings, and churches on the Lord's Day, at Christmas time and during confirmation. In the Homoród-valley, two branches are placed on both sides of the doorway of wedding-houses, ornamented by a bouquet for the bride, and by a jar of wine for the bridegroom. In winter, wedding-houses are decorated with the branches of spruces instead of birch. On May 1st, 2-5 meter long birch branches are erected by young men in front of the houses of unwed young women as a special gift for a week. 


\section{Discussion}

The parts of silver birch were documented in various application forms in home treatments, tools and customs in the studied Csángó and Székely villages, and the data were compared with earlier records in Transylvania and some records from other European countries.

Leaf decoctions were documented not only as a single remedy, but also blended with other taxa, in contrast to the earlier Transylvanian data or records in other countries (Tab. 2). Among the ethnomedicinal use of the leaves for rheumatism, they were used in trousers, and in bed or sacks similarly to earlier data obtained in Transylvania [9,45-50], and to its use as an analgesic in Poland [51,52]. However, while the use of leaf decoctions for dyeing and for hair loss in Transylvania was reported recently and earlier [9,53], as well as in Montenegro [54], the current data for flatulence and for sweating of the legs were not found in literature sources (Tab. 2). The external use of bark for skin disorders was also recorded in Albania and Macedonia (Pieroni, unpublished), while its internal use was mentioned in Bosnia and Herzegovina and in Kosovo [55-58]. In our work, no data were recorded on the use of the tar (Betulae pix), in contrast to earlier reports in the country $[59,60]$. For diarrhoea in veterinary practice, the decoction of the bark was mentioned earlier in Transylvania [61], while the use of the leaf for the same purpose was also reported in Italy [62].

The harvesting of birch water was described in several previous reports in Transylvania, and in Germany and

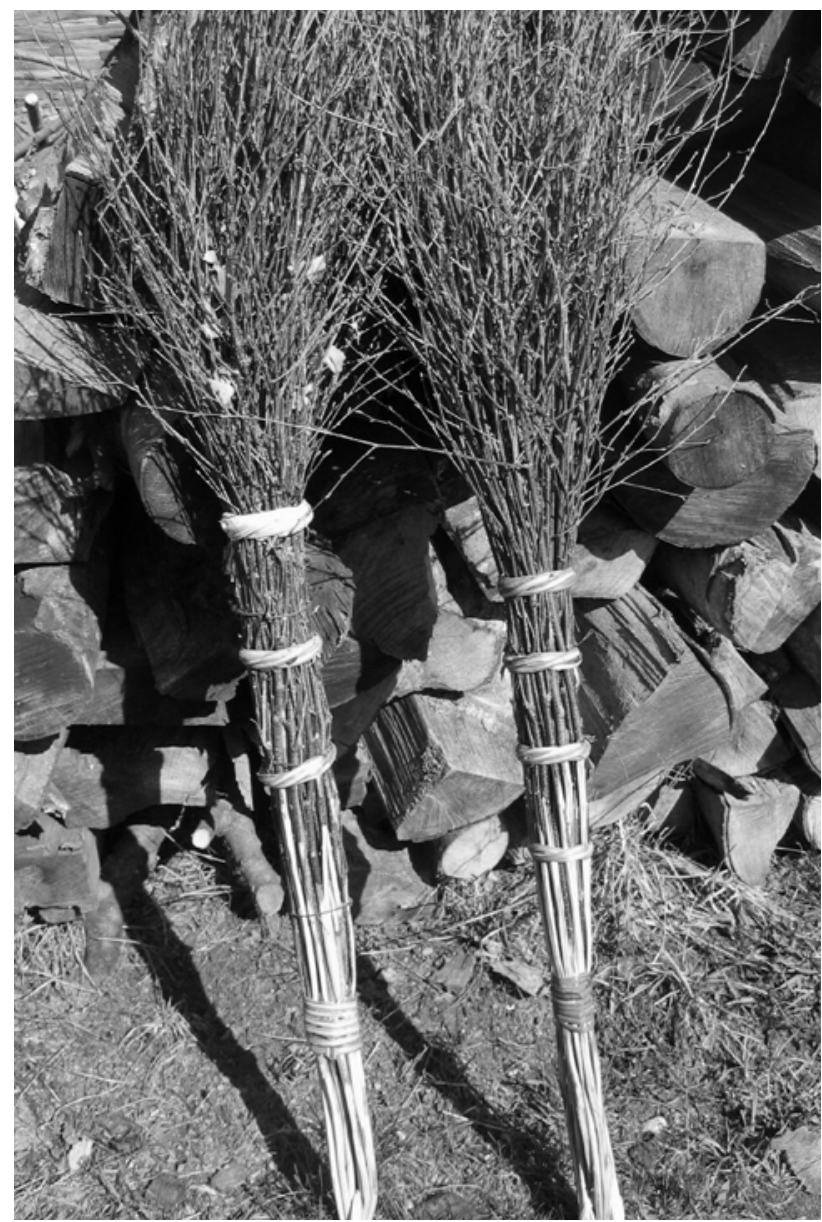

Fig. 6 First type of brooms from birch branches.
Russia $[63,64]$. In the 18th-19th century, birch sap (virics) was harvested regularly and sold in the markets, playing an important role in the livelihood of the rural classes [31]. Nowadays, traditional collection of birch sap called viricselés appears as an underrepresented and evanescent phenomenon, including mostly oral and little manual demonstration of the detailed method. During the collection, four special section types of the trunk were documented in the studied Transylvanian areas. The birch water was used in itself or with milk [65], both externally and internally (Tab. 2). It was also used as a beverage, as wine and beer, similarly to some earlier reports in the country [14,36]. As a novel data, informants have mentioned headache due to the excessive use of the sap in Homoród. The previous record for its use as vinegar (Tab. 2) was also found in Sweden, Estonia, Poland, Slovakia, Ukraine, Russia, Britain and Ireland [65-78], without any record of this documented in our field work. The significance of silver birch as a milk-rennet plant was recorded only in previous reports in the country [26,27], and in the Netherlands and Finland [77,78].

Among the uses of the leafy branches in tools, the preparation of brooms was commonly documented in each settlement (Tab. 2) similarly to some earlier records $[5,9,61,79]$. The common use of the woody parts as firewood was also recorded because of the easily ignitable bark of the species, while its use as a torch was reported in other countries [5]. In addition, branches were used in special protective rituals in the studied Csángós' areas on St. George's day (April 24th), and in ceremonies such as zödág in the Székelys region,

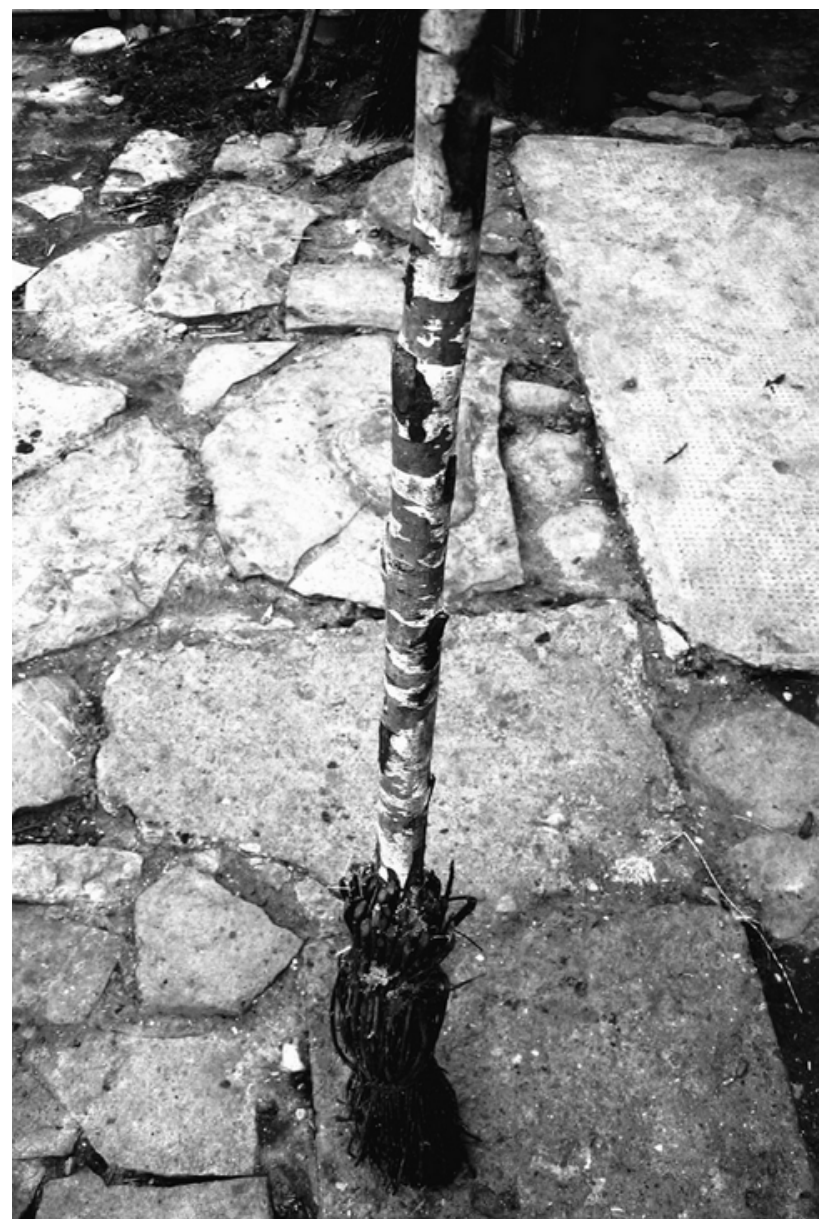

Fig. 7 Second type of brooms (csutak) from birch branches. 
corresponding to the previous work in Kalotaszeg [11], and to earlier data from Netherlands, Germany, Belgium, northeastern Italy, Central Europe and South Western Balkans $[5,80]$ (Pieroni, unpublished data). These customs can be described as a disappearing phenomenon in Transylvania nowadays.

The blessed leafy branches are used at Whitsunday or in weddings in the studied settlements, which are ornamented with a bouquet or a jar in Homoród, and with wreaths in the Russian folklore. The protective role of the branches against bad weather (storms) was recorded mostly in the Csángó region, while against bad spirits in Russia and Sweden [7].

\section{Conclusions}

Although the traditional knowledge documented in this data is based on the memories of the ancestors and on the personal experiences of the people, a relatively low proportion of the traditional knowledge about $B$. pendula was observed among the studied ethnic groups of Csángós and Székelys from an agricultural, ethnobotanical and

\section{Acknowledgments}

This work was supported by the OTKA (Hungarian Scientific Research Fund) grant (PD 108534). We are grateful for the help of the informants of the villages, and for Tamás Grynaeus†, Kata Birkás-Frendl, Mária and Mihály Péter for the instructions, and for Imre Gábos, János Gábos, Géza Szentpáli, Enikő and Mihály Benedek, as well as Judit Laki and Veronika Martos for their assistance.

\section{Authors' contributions}

The following declarations about authors' contributions to the research have been made: initiation of the work, field work and the first version of the paper: NP; literature survey: NP, DC, TM, KC, AP; participation in the writing process: $\mathrm{DC}, \mathrm{AH}, \mathrm{TM}, \mathrm{CLQ}$; helping to evaluate the results and discussion: AP.

\section{References}

1. Tutin TG, Burges NA, Charter AO, Edmondson JR, Heywood VH, Moore DM, et al., editors. Flora Europaea. Cambridge: Cambridge University Press; 2010. (vol 1).

2. Szabó LG. Gyógynövény-ismereti tájékoztató. Baksa: Schmidt und Co.; 2005.

3. Alejano R, Martinez Montes E, Bengoa J. Betula pendula en la Sierra de las Villas. Ecologia. 1993;7:203-213.

4. Gencsi L, Vancsura R. Dendrológia. Budapest: Mezőgazda; 1992.

5. Bock H. Kräuterbuch. Straßburg: 1539.

6. de Cles B, Bellomaria B, Berdini C, Pedrotti F, da Trieste F, de Cles M. Le ricette fitoterapeutiche del barone Bernardo de Cles. Camerino: Università di Camerino; 2000.

7. Cleene M, Lejeune MC. Compendium of symbolic and ritual plants in Europe: herbs. Ghent: Man \& Culture; 2002. (vol 1).

8. Rácz J. Növénynevek enciklopédiája: az elnevezések eredete, a növények kultúrtörténete és élettani hatása. Budapest: Tinta; 2010.

9. Plinius GS. Naturalis historia [reprint]. Budapest: Natura; 1987.

10. Sandor K. Nyelvrokonsag es hunhagyomany. Budapest: Typotex; 2011.

11. Péntek J, Szabó A. Ember és növényvilág: kalotaszeg növényzete és népi növényismerete. Bucharest: Kriterion; 1985. ethnopharmacological point of view. In addition to the existing data concerning the use of the leaves and woody parts, the use of the tar was observed as a disappeared element. Our findings add new values about birch water (virics) to the observations described earlier, but this also indicates that its consumption and multiple use has been progressively lost, similarly to the old harvesting methods in Transylvania and all over in Romania.

The ethnobotanical and ethnomedicinal data display a declining tendency in the region from day to day, largely influenced by migration trends and the employment of youth far from their ancestral lands. Moreover, the increasingly frequent use of phytotherapeutic books and other outside sources also influences the traditional knowledge of people, which is incorporated in the daily medical practices of people. Consequently, collection fieldtrips in the ethnobotanically unexplored and isolated regions of Transylvania are of primary importance nowadays, and should focus on the maintenance of ancestral harvesting techniques and ethnomedicinal elements. Such studies can also be useful for informing future phytotherapeutical research on key local ethnomedicinal resources, such as birch sap.

12. Tarisznyás M. A gyüjtögető gazdálkodás hagyományai Gyergyóban. In: Kós K, Faragó J, editors. Népismereti dolgozatok. Bucharest: Kriterion; 1978. p. 25-33.

13. European Pharmacopoeia. 7th ed. Strasbourg: Council of Europe; 2010.

14. Demirci B, Paper DH, Demirci F, Can Başer KH, Franz G. Essential oil of Betula pendula Roth. buds. Evid Based Complement Alternat Med. 2004;1(3):301-303. http://dx.doi.org/10.1093/ecam/neh041

15. Romanian Pharmacopoeia X. Bucharest: Medicală; 1993.

16. Borza A, Beldie A. Dicționar etnobotanic. Bucharest: Editura Academiei Republicii Socialiste România; 1968.

17. Gazda K. Gyermekvilág Esztelneken: néprajzi monográfia. Bucharest: Kriterion; 1980.

18. Butură V. Enciclopedie de etnobotanică românească. Bucharest: Editura Științifică și Enciclopedică; 1979.

19. Boris G. Gyógynövények népi használata a székelyföldi Lövétén [BSc thesis]. Pécs: Univeristy of Pécs; 2010.

20. Péntek J, Szabó TA. Egy háromszéki falu népi növényismerete. Ethnographia. 1976;87(1-2):203-225.

21. Szendrey Z. A növény-, állat- és ásványvilág a varázslatokban. Ethnographia. 1937;48(1):154-166.

22. Mayer JG, Saum K, Uehleke B. Kolostori gyógyászat. Budapest: Magyar Könyvklub; 2004.

23. Kallio H, Karppinen T, Holmbom B. Concentration of birch sap by reverse osmosis. J Food Sci. 1985;50(5):1330-1332. http://dx.doi. org/10.1111/j.1365-2621.1985.tb10470.x

24. Kallio H, Rine S, Pangborn RM, Jennings W. Effect of heating on the headspace volatiles of Finnish birch syrup. Food Chem. 1987;24(4):287-299. http://dx.doi.org/10.1016/0308-8146(87)90104-X

25. Kallio H, Ahtonen S. Seasonal variations of the acids in birch sap. Food Chem. 1987;25(4):285-292. http://dx.doi. org/10.1016/0308-8146(87)90015-X

26. Melius P. Herbárium. Bucharest: Kriterion; 1979.

27. Gunda B. Tejoltó növények a Kárpátokban. Ethnographia. 1967;78:161-175.

28. Halászné ZK. Adatok a moldvai magyarok gyógynövény-használatához. Gyógyszerészet. 1981;25:361-367.

29. Zillmann J. Népi gyógyászat Havadon. Néprajzi Látóhatár. $1997 ; 1-2: 124$. 
30. Keszeg V. A mezőségi Detrehemtelep népi gyógyászata. In: Népismereti dolgozatok. Bucharest: Kriterion; 1981. p. 97-117.

31. Györffy I. Viricselés a Székelyföldön. Ethnographia. 1937;48(2-3):205-220.

32. Kalašaitytè L. Liaudies medicinos priemonès. In: Vèlius $\mathrm{N}$, editor. Gervèčiai. Vilnius: Mintis; 1989. p. 204-219.

33. Brøndegaard VJ. Folk og flora: Dansk etnobotanik. Copenhagen: Rosenkilde og Bagger; 1978. (vol 1-2).

34. Rácz G, Füzi J, editors. Kovászna megye gyógynövényei. Sfântu Gheorghe: Directory of Agriculture, Food and Hydrography; 1973.

35. Gunda B. Nyírvíz (szócikk). In: Magyar Néprajzi Lexikon (N-Szé). Budapest: Akadémiai Kiadó; 1987. p. 62. (vol 4).

36. Kiss L. A nyírvíz. Földgömb. 1929;1:1-6.

37. Gunda B. Irodalmi szemle. Ethnographia. 1941;52(1):154-155.

38. Rab J, Tankó $P$, Tankó M. Népi növényismeret Gyimesbükkön. In: János VA, Károly K, József F, editors. Népismereti dolgozatok. Bucharest: Kriterion; 1981. p. 23-38.

39. Szebeni G. A csíki juhászat. Ethnographia. 1972;73(1):54-89.

40. Bartos T. Magyar szótár: egymást magyarázó szavak és fordulatok tára. Budapest: Corvina; 2002. (vol 1).

41. Rab J. Az etnogeobotanika mint történeti ökológiai segédtudomány. In: Várkonyi RA, Kósa L, editors. Európa híres kertje. Budapest: Orpheusz; 1993. p. 223-257.

42. Babai D, Molnár Z. Népi növényzetismeret Gyimesben II.: Termőhelyés élőhelyismeret. Bot Közl. 2009;96(1-2):145-173.

43. Hammer K, Laghetti G, Pignone D, editors. Linguistic islands and plant genetic resources - the case of the Arbëreshë. Rome: Aracne; 2011.

44. Newing H. Conducting research in conservation: social science methods and practice. New York, NY: Routledge; 2011.

45. Kóczián G, Pintér I, Gál M, Szabó I, Szabó L. Etnobotanikai adatok Gyimesvölgyéből. Bot Közl. 1976;63(1):29-35.

46. Gub J. Adatok a Nagy-Homoród és a Nagy-Küküllő közötti terület népi növényismeretéhez. Néprajzi Látóhatár. 1993;1-2:95-110.

47. Gub J. Népi növényismeret a Nagy-Homoród mentén. In: Zsigmond G, editor. Növények a folklórban. Bucharest: A Magyar Köztársaság Kulturális Intézete; 2005. p. 148-162.

48. Szabó LG. Népi gyógynövény-ismeret Kalotaszegen és Gyimesvölgyében. Turán. 2002;5(4):39-52.

49. Vajkai A. Népi orvoslás a Borsavölgyében. Cluj Napoca: Erdélyi Tudományos Intézet; 1943.

50. Rab J. Újabb népgyógyászati adatok Gyimesből. Gyógyszerészet. 1982;26:325-333.

51. Kukier R. Kaszubi bytowscy: zarys monografii etnograficznej. Gdynia: Wydawnictwo Morskie; 1968.

52. Paluch A. Świat roślin w tradycyjnych praktykach leczniczych wsi polskiej. Wrocław: Wrocław University Press; 1984.

53. Miklóssy VV. Festőnövények a csíki háziiparban. In: Népismereti dolgozatok. Bucharest: Kriterion; 1978. p. 91-100.

54. Menković N, Šavikin K, Tasić S, Zdunić G, Stešević D, Milosavljević $\mathrm{S}$, et al. Ethnobotanical study on traditional uses of wild medicinal plants in Prokletije Mountains (Montenegro). J Ethnopharmacol. 2011;133(1):97-107. http://dx.doi.org/10.1016/j.jep.2010.09.008

55. Šarić-Kundalić B, Dobeš C, Klatte-Asselmeyer V, Saukel J. Ethnobotanical study on medicinal use of wild and cultivated plants in middle, south and west Bosnia and Herzegovina. J Ethnopharmacol. 2010;131(1):33-55. http://dx.doi.org/10.1016/j.jep.2010.05.061

56. Šarić-Kundalić B, Dobeš C, Klatte-Asselmeyer V, Saukel J. Ethnobotanical survey of traditionally used plants in human therapy of east, north and north-east Bosnia and Herzegovina. J Ethnopharmacol. 2011;133(3):1051-1076. http://dx.doi.org/10.1016/j.jep.2010.11.033
57. Mustafa B, Hajdari A, Krasniqi F, Hoxha E, Ademi H, Quave CL, et al. Medical ethnobotany of the Albanian Alps in Kosovo. J Ethnobiol Ethnomed. 2012;8(1):6. http://dx.doi.org/10.1186/1746-4269-8-6

58. Mustafa B, Hajdari A, Pajazita Q, Syla B, Quave CL, Pieroni A. An ethnobotanical survey of the Gollak region, Kosovo. Genet Resour Crop Evol. 2012;59(5):739-754. http://dx.doi.org/10.1007/ s10722-011-9715-4

59. Csedő K, editor. Plantele medicinale şi condimentare din județul Harghita. Hargita megye gyógy- és füszernövényei. Târgu Mureş: Tipografia Tirgu Mures; 1980.

60. Rácz G, Rácz-Kotilla E, Laza A. Gyógynövényismeret. Bucharest: Ceres; 1984.

61. Kóczián G, Pintér I, Szabó LG. Adatok a gyimesi csángók népi gyógyászatához. Gyógyszerészet. 1975;19:226-230.

62. Guarrera P. Usi e tradizioni della flora italiana: medicina popolare ed etnobotanica. Rome: Aracne; 2006.

63. Dieck AC. Die Birke (Betula L.) in der Volksmedizin Europas. Curare. 1985;3:85-94.

64. Zyryanova OA, Terazawa M, Koike T, Zyryanov VI. White birch trees as resource species of Russia: their distribution, ecophysiological features, multiple utilizations. Eurasian J Res. 2010;13:25-40.

65. Svanberg I, Sõukand R, Łuczaj Ł, Kalle R, Zyryanova O, Dénes A, et al. Uses of tree saps in northern and eastern parts of Europe. Acta Soc Bot Pol. 2012;81(4):343-357. http://dx.doi.org/10.5586/asbp.2012.036

66. Cronquist AW. Illustrerad ordbok öfver näringsämnen och handelsartiklar. Stockholm: Hæggström; 1879.

67. Berg G. Nordskandinaviskt - nordeuropeiskt. Rig. 1933;16:118-139.

68. Berg G. Att tappa björklake. Gastron Kal. 1969:35-57.

69. Vuorela T. Suomensukuiset kansat. Helsinki: Suomalaisen Kirjallisuuden Seura; 1960.

70. Markus M. L’udova stravá. In: Mjartan J, editor. Banícka dedina Žakarovce. Bratislava: Vydavatel'stvo Slovenskej Akadémie; 1956. p. 283-324.

71. Rebane H. Voolab kasemahl. Eesti Lood. 1977;4:223-228.

72. Toren MD. Russkaya narodnaya meditsina i psikhoterapiya. St. Petersburg: Litera; 1996

73. Allen DE, Hatfield G. Medicinal plants in folk tradition: an ethnobotany of Britain \& Ireland. Portland, OR: Timber Press; 2004

74. Łuczaj Ł. Archival data on wild food plants used in Poland in 1948. J Ethnobiol Ethnomed. 2008;4(1):4. http://dx.doi. org/10.1186/1746-4269-4-4

75. Fischerström J. Nya Swenska economiska dictionnairen. Eller Forsook til ett Allmänt och fullständigt lexicon i Swenska hushållningen och naturläran. Stockholm: Carl Stolpe; 1780. (vol 2).

76. Hupel AW. Topographische Nachrichten von Lief- und Ehstland: Nebst vollständigen Register über alle drey Bände. Riga: JF Hartknoch; 1777.

77. Hildebrand S. En holländsk beskicknings resa. Stockholm: Sune Hildegard; 1917.

78. Lange J. Løvetræer, in Kulturhistoriskt lexikon för nordisk medeltid. Malmö: Allhem; 1966. (vol 11).

79. Nedelcheva AM, Dogan Y, Guarrera P. Plants traditionally used to make brooms in several European countries. J Ethnobiol Ethnomed. 2007;3(1):20. http://dx.doi.org/10.1186/1746-4269-3-20

80. Hoffmann-Krayer E, Bächtold-Stäubli H. Handwörterbuch des deutschen Aberglauben. Berlin: Walter de Gruyter; 1927.

81. Feszt G, Rácz-Kotilla E, Fórika M, Pálffy B. A nyírfa tavaszi nedvének hatása vesekövekre "in vitro" és kísérletes nephrolithiasisban. Orvosi Szle. 1966;12(3):285-287.

82. Tita I, Mogosanu GD, Tita MG. Ethnobotanical inventory of medicinal plants from the south-west of Romania. Farmacia. 2009;57(82):141-156. 
83. Pieroni A, Giusti ME, Quave CL. Cross-cultural ethnobiology in the Western Balkans: medical ethnobotany and ethnozoology among Albanians and Serbs in the Pešter plateau, Sandžak, south-western Serbia. Hum Ecol. 2011;39(3):333-349. http://dx.doi.org/10.1007/ s10745-011-9401-3

84. Łuczaj Ł. A relic of medieval folklore: Corpus Christi Octave herbal wreaths in Poland and their relationship with the local pharmacopoeia. J Ethnopharmacol. 2012;142(1):228-240. http://dx.doi.org/10.1016/j. jep.2012.04.049

85. Krylov GV, Stepanov EV. Zelenaya apteka Kuzbassa. 2nd ed. Kemerovo: Kemerovskoe knizhnoe izdatel'stvo; 1979. 